\title{
FLAVONOIDS AND BIOLOGICAL ACTIVITIES OF CENTAUREA NERIMANIAE S. KULTUR
}

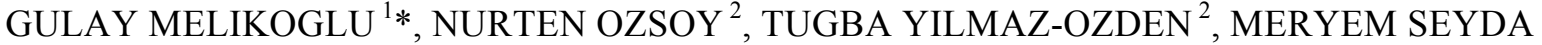 \\ ERBAY ${ }^{1}$, SEZIN ANIL ${ }^{1}$, BERNA OZBEK CELIK $^{3}$, SUKRAN KULTUR ${ }^{4}$ \\ ${ }^{I}$ Department of Pharmacognosy, Faculty of Pharmacy, Istanbul University, 34116 Istanbul, Turkey \\ ${ }^{2}$ Department of Biochemistry, Faculty of Pharmacy, Istanbul University, 34116 Istanbul, Turkey \\ ${ }^{3}$ Department of Pharmaceutical Microbiology, Faculty of Pharmacy, Istanbul University, 34116 Istanbul, Turkey \\ ${ }^{4}$ Department of Pharmaceutical Botany, Faculty of Pharmacy, Istanbul University, 34116 Istanbul, Turkey \\ *corresponding author: gulaymelikoglu@hotmail.com
}

Manuscript received: January 2018

\begin{abstract}
Centaurea nerimaniae S. Kultur, an endemic species from the Turkish flora, distributed in south Anatolia (Icel Province) was investigated for its flavonoids and in vitro antioxidant, anti-cholinergic, anti-inflammatory and antibacterial activities. The phytochemical investigation of the plant led to the isolation of five flavonoids, identified as cirsimaritin, hispidulin, apigenin, isokaempferide and apigenin 7-O-glucoside. In addition to its ability to inhibit AChE and lipid peroxidation, induced by $\mathrm{Fe}^{3+}$ /ascorbate system, scavenge DPPH radicals, and to reduce $\mathrm{Fe}^{3+}$ to $\mathrm{Fe}^{2+}$, the extract showed strong COX-1 and COX-2 inhibitory and antimicrobial activities, suggesting that this plant could act as an antioxidant and anti-inflammatory agent against disorders, associated with oxidative damage, as well as an effective phytotherapeutic agent against some fungal and bacterial diseases.
\end{abstract}

\section{Rezumat}

Centaurea nerimaniae S. Kultur, o specie endemică din flora Turciei, a fost investigată pentru conţinutul în flavonoide pentru activitățile antioxidante, anticolinergice, antiinflamatoare și anti-bacteriene. Investigarea fitochimică a plantei a condus la izolarea a cinci flavonoide: cirsimaritină, hispidulină, apigenină, izokaempferidă şi 7-O-glucozid apigenină. Testele biochimice sugerează că această plantă ar putea acționa ca antioxidant și anti-inflamator în tulburările asociate leziunilor oxidative, precum și ca un produs fitoterapeutic eficient împotriva unor boli fungice și bacteriene.

Keywords: Centaurea nerimaniae S. Kultur, flavonoids, antioxidant, anti-acetylcholinesterase, anti-inflammatory, antimicrobial activity

\section{Introduction}

Considering the rich variety of medicinal plants commonly grown and used in Turkey and the high prevalence of cancer, cardiovascular, inflammatory and neurodegenerative diseases, more investigations should be carried out in order to understand the beneficial effects of Turkish medicinal plants [33]. The genus Centaurea is represented by 217 species and $60 \%$ of which are endemic in Turkey [9]. Centaurea nerimaniae, named in the honour of the Turkish botanist Prof. Dr. Neriman Özhatay, is an endemic species distributed in south Anatolia (Icel Province) [28].

Centaurea species are used in folk medicine because of their digestive, expectorant, antidiarrheal, tonic, and antipyretic properties [5].

These species have been extensively studied mainly for their antioxidant $[1,2,24,34,46-48]$, antimicrobial [20, 23, 27, 43, 44], acetylcholinesterase (AChE) inhibitory [2, 34], antiinflammatory and wound healing [25] as well as analgesic properties
[26]. There are some reports attributing the antiinflammatory effects of Centaurea species or its ingredients to inhibition of NF-kB activation, reduction of expression of COX-2 and iNOS [17, 46].

Phytochemical studies have shown that the main components of Centaurea sp. are sesquiterpene lactones, acetylenes and flavonoids [3].

Previous phytochemical screening showed that Centaurea species contain flavonoids including apigenin, luteolin, salvigenin, kaempferol, hispidulin and cirsimaritin, and sesquiterpene lactones of the guianolide type as diain, cynaropicrin, deacyclocynaropicrin and janerin [6]. Formisano et al. summarized the distribution of flavonoids in 112 Centaurea species [18].

However, there are no reports regarding the phytochemicals as well as biological activities of Centaurea nerimaniae. Isolation of flavonoids and evaluation the therapeutic potential of Centaurea nerimaniae by examining its antioxidant, anti-inflammatory, antimicrobial and anticholinesterase properties is aimed in this study. 


\section{Materials and Methods}

\section{Plant material}

The plant material of Centaurea nerimaniae S. Kultur were collected from Mersin Province, near Arslanköy location (Turkey) and identified by Prof. Dr. Şükran Kültür at Istanbul University, Pharmaceutical Botany Department, in June 2012. Voucher specimens were maintained in the Herbarium of Istanbul University, Faculty of Pharmacy, Istanbul, Turkey (ISTE 98163).

Extraction and isolation

The dried aerial parts ( $900 \mathrm{~g}$ ) of C. nerimaniae were first subjected to extraction with petroleum ether and then with $\mathrm{EtOH}\left(95^{\circ}\right)$ in a Soxhlet apparatus. The petroleum ether extract (A) was concentrated and extracted with $60 \%$ ethanol. The aqueous extract was concentrated and extracted with chloroform (B) in a separator funnel. The concentrated ethanol $\left(95^{\circ}\right)$ extract was diluted with $\mathrm{H}_{2} \mathrm{O}$ and successively extracted with benzene (C), chloroform (D) and ethyl acetate (E) for fractionation.

For the purification of flavonoids from the B, D and E extracts, silica gel column chromatography, paper chromatography and preparative TLC (thin-layer chromatography) were applied. As a result of this work cirsimaritin and hispidulin were isolated from the petroleum ether-chloroform (B), apigenin and 1sokaempferide were isolated from the ethanolchloroform (D), and apigenin 7-O-glucoside was isolated ethanol-ethyl acetate (E) extracts. The structures of the pure compounds were elucidated based on $R f$ values, colour reactions and spectroscopic methods in comparison with standards or with reference data.

The dried aerial parts $(50 \mathrm{~g})$ of the plant were extracted with methanol in a Soxhlet apparatus. The methanol extract was evaporated to dryness by a rotary evaporator. The extract was kept at $-20^{\circ} \mathrm{C}$ and was then lyophilized. In this way, the crude methanolic extract was obtained and used for biological activity studies.

Biochemical assays

In the present study, the extract was screened for its antioxidant activity using thiobarbarbituric acid (TBA) test based on the lipid peroxidation of liposomes [15], 2,2-diphenyl-1-picrylhydrazyl (DPPH) free radical scavenging [10], Trolox equivalent antioxidant capacity (TEAC) assay with 2,2'-azino-bis(3-ethylbenzothiazoline-6-sulphonic acid) $\left(\mathrm{ABTS}^{\bullet+}\right.$ ) radical cation [37] and ferric reducing ability of plasma (FRAP) assay [7]. Quercetin was used as reference antioxidant.

The extracts total phenolic compounds were evaluated using Folin-Ciocalteu reagent according to Slinkard and Singleton method [42] and expressed as means $\mathrm{mg}$ gallic acid equivalents (GAE)/g of dry weight (DW). Total flavonoids were evaluated by $\mathrm{AlCl}_{3}$ colorimetric method described by Sakanaka et al. [39] and expressed as $\mathrm{mg}$ catechin equivalents $(\mathrm{CE}) / \mathrm{g}$ of DW.

Inhibition or radical scavenging activities (\%) of the extract were calculated according to the equation:

Inhibition or radical scavenging activity (\%) = [1(Absorbance of sample/Absorbance of control)]x 100.

The AChE inhibitory activity of the extract was determined by the method of Ellman et al. [16]. Galantamine was used as a standard AChE inhibitor and distilled water was used as a control.

COX-1 and COX-2 inhibitory activities of the extract were determined by calculating the inhibition percent of prostaglandin production measured by enzyme immunoassay kit following the manufacturer's protocol (Cayman). Indomethacin was used as a standard. Antibacterial and antifungal effects

Antibacterial and antifungal effects of the extract were determined by the microbroth dilutions technique performed in accordance with the recommendations in the Clinical Laboratory Standards Institute (CLSI) document M7-A5 and M 27-A [12, 13]. The minimum inhibitory concentration (MIC) values of the extract against studied microorganisms were determined.

Statistical analysis

Results were expressed as a mean \pm standard deviation. Statistical comparisons were performed with Student's $t$-test. Differences were considered significant at $\mathrm{p}<0.05$.

\section{Results and Discussion}

Isolated compounds

In the present study, five flavonoid compounds were obtained from the aerial parts of $C$. nerimaniae. These compounds were characterized as cirsimaritin (B ext., $6 \mathrm{mg}$ ), hispidulin (D ext. $9 \mathrm{mg}$ ), apigenin (D ext. $5 \mathrm{mg}$ ), isokaempferide (E ext. $7 \mathrm{mg}$ ) and apigenin 7-O-glucoside (E ext. $22 \mathrm{mg}$ ) by UV spectral data compared with the data in the literature [19, 29, 36]; and by TLC comparison with reference standards (Table I). Apigenin 7-O-glucoside was the major compound.

Similarly, Nikolova and Bancheva [31] have reported that Centaurea species are rich sources of externally accumulated flavonoid aglycones such as luteolin, apigenin, 6-hydroxyluteolin 6-methyl, kaempferol 3-methyl and scutellarein 6,4'-dimethyl ethers. They reported that 6-hydroxyluteolin, methyl derivatives of scutellarein and 6-Osubstituted flavones are found in the exudates of Centaurea davidovii and C. parilica, while 6-Osubstituted flavonols, such as quercetagetin, methyl derivatives of 6-hydroxykaempferol and flavonols with 3-methylation are found in exudates of $C$. stenolepsis. 
UV data for flavonoids from $C$. nerimanieae $(\lambda \max )$

\begin{tabular}{|c|c|c|c|c|c|c|}
\hline Flavonoid & MeOH & NaOMe & $\mathbf{A l C l}_{\mathbf{3}}$ & $\mathbf{A I C l}_{\mathbf{3}} / \mathbf{H C l}$ & $\mathbf{N a O A c}$ & $\mathbf{N a O A c}_{\mathbf{H}} \mathbf{H}_{\mathbf{3}} \mathbf{B O}_{\mathbf{3}}$ \\
\hline Cirsimaritin & 332,285 & 370,287 & $\begin{array}{c}364,302,285 \mathrm{sh}, \\
263\end{array}$ & $\begin{array}{c}354,300,285 \mathrm{sh}, \\
262 \mathrm{sh}\end{array}$ & $\begin{array}{c}388 \mathrm{sh}, 335, \\
278\end{array}$ & 333,280 \\
\hline Hispidulin & 335,273 & $393,327,275$ & $\begin{array}{c}390 \mathrm{sh}, 360,303, \\
279 \mathrm{sh}, 263\end{array}$ & $\begin{array}{c}390 \mathrm{sh}, 352,300 \\
\text { sh, 280,260 sh }\end{array}$ & $\begin{array}{c}370,308 \mathrm{sh}, \\
297 \mathrm{sh}, 274\end{array}$ & 337,254 \\
\hline Apigenin & $336,296 \mathrm{sh}, 267$ & $392,324,275$ & $384,348,301,276$ & $381,340,299,276$ & $376,301,274$ & $338,302 \mathrm{sh}, 268 \mathrm{sh}$ \\
\hline Isokaempferide & 352,268 & $404,329,276$ & $396,345,303,277$ & $396,345,303,277$ & $365,301,275$ & 361,257 \\
\hline $\begin{array}{c}\text { Apigenin 7-O- } \\
\text { glucoside }\end{array}$ & 333,268 & $386,301 \mathrm{sh}$, & $386,348,300,276$ & $382,341,299,277$ & $\begin{array}{c}387,355,267, \\
256 \mathrm{sh}\end{array}$ & 340,267 \\
\hline
\end{tabular}

$\mathrm{sh}=$ shoulder

Formisano et al. [18] reviewed reports on flavonoids from the Centaureinae subtribe of the family Asteraceae, as well as the ${ }^{13} \mathrm{C}$-NMR-spectral data in the literature pointed out that only 16 of the 72 recognized genera of the subtribe Centaureinae have been investigated for the occurrence of flavonoids. From the data reported by Formisano et al. [18], it was seen that the majority of the genera of the Centaureinae have not been investigated for their flavonoid profile yet.

The results of the chemical characterization of $C$. nerimaniae reconfirmed the value of the Centaurea genus as a source of the flavonoid aglycons.

Our results were in accordance with the flavonoid composition of the Centaurea species from the Turkish flora [45].

Total phenolic and flavonoid contents. The total phenolic content of $C$. nerimaniae was $2.23 \pm 0.11 \mathrm{mg}$ $\mathrm{GAE} / \mathrm{g}$ DW, while the flavanoid level was $1.25 \pm$ $0.10 \mathrm{mg} \mathrm{CE} / \mathrm{g}$ DW (Table II).

Table II

Total extractable compounds (EC), total phenolic compounds (PC, as gallic acid equivalents) and total flavonoids (as catechin equivalents) of the methanol extract of $C$. nerimaniae \begin{tabular}{|l|c|c|c|c|}
\hline & EC (mg/g DW) & Phenolic compounds (PC) (mg GAE/g DW) & Flavonoids (mg CE/g DW) & PC/EC (\%) \\
\hline C. nerimaniae & 96.25 & $2.23 \pm 0.11$ & $1.25 \pm 0.10$ & 2.32 \\
\hline
\end{tabular}

Values were the means of three replicates \pm standard deviation

Many earlier studies showed that the aerial part of Centaurea species is an alternative source of phenolic compounds. Comparing to other Centaurea species collected from Turkey, it was evident that the phenolic content of Centaurea nerimaniae is lower than the values found for Centaurea species investigated by Aktumsek et al. [1] (ranged from 82.27 to $175.40 \mathrm{mg}$ GAE/g extract), Centaurea species investigated by Şen et al. [41] (ranged from 4.825 to $12.460 \mathrm{mg}$ GAE/g DW), and Centaurea species investigated by Aktumsek et al. [2] (ranged from 207.78 to 232.78 $\mathrm{mg} / \mathrm{g}$ extract).

A similar content of phenolic compounds were reported by Zengin et al. [47] for Centaurea urvillei subsp hayekiana (17.22 mg GAE/g extract), Zengin et al. [46] for C. pulchella, C. patula and C. tchihatcheff (ranged from 22.27 to $55.00 \mathrm{mg}$ GAE/g extract), Ozsoy et al. [34] for Centaurea antiochia var. praealta (3.68 mg GAE/g DW) and Uysal et al. [45] for Centaurea urvillei subsp. stepposa (33.11 mg GAE/g extract).

Quercetin, apigenin and kaempferol, the most common flavonoids present in Centaurea species, may contribute to the antioxidant activity.

Antioxidant activity

Centaurea species have been the subject of intense research for their antioxidant properties. In this study
TBA method, which evaluates the ability of an antioxidant to inhibit lipid peroxidation and DPPH radical scavenging assays were chosen as representative of hydrogen transfer, while TEAC and FRAP methods were chosen as representative of single electron transfer reaction based assays.

Table III presents the results of antioxidant activities of the extract, expressed as $\mathrm{EC}_{50}$, TEAC and FRAP values.

Compared to DPPH radicals, the methanolic extract of the aerial parts from Centaurea nerimaniae was found to be more effective ABTS radical cation scavenger. The highest $\mathrm{E}_{50}$ value was found in TBA test, showing the less ability of the extract to protect liposomes from lipid peroxidation. TEAC value was similar to the FRAP value, which indicates that the extract is effective in donating of electrons. However, the results showed a weak antioxidant activity compared to the reference antioxidant quercetin. Although, the extract was less active than quercetin $(\mathrm{p}<0.05)$, it was seen that it has hydrogen and a single electron donor activities, thus could serve as an antioxidant. These activities may be attributed mostly to the presence of the phenolic group, a feature common to natural phenolic compounds. 
Half maximal effective concentration $\left(\mathrm{EC}_{50}\right)$, Trolox equivalents antioxidant capacity (TEAC) and ferric reducing antioxidant power (FRAP) values of methanol extract of $C$. nerimaniae

\begin{tabular}{|c|c|c|c|c|c|}
\hline & \multicolumn{3}{|c|}{ EC $_{\mathbf{5 0}}(\mathbf{m g} / \mathbf{m L})^{\mathbf{A}}$} & & \\
\cline { 2 - 6 } & DPPH & ABTS & Anti-LPO & FRAP $^{\mathrm{B}_{*}}(\mathbf{m M})$ & TEAC $^{\mathbf{C}}(\mathbf{m M})$ \\
\hline C. nerimaniae & $5.81 \pm 0.94^{\mathrm{a}}$ & $4.55 \pm 0.19^{\mathrm{a}}$ & $11.87 \pm 0.56^{\mathrm{a}}$ & $2.45 \pm 0.18^{\mathrm{a}}$ & $1.89 \pm 0.05^{\mathrm{a}}$ \\
\hline Quercetin & $0.098 \pm 0.001^{\mathrm{b}}$ & $0.155 \pm 0.012^{\mathrm{b}}$ & $0.062 \pm 0.005^{\mathrm{b}}$ & $2.34 \pm 0.010^{\mathrm{a}}$ & $1.98 \pm 0.03^{\mathrm{a}}$ \\
\hline
\end{tabular}

Values were the means of three replicates \pm standard deviation. Values with different letters in the same column were significantly (p $<0.05$ ) different. ${ }^{\mathrm{A}} \mathrm{EC}_{50}$ value: The effective concentration at which the antioxidant activity was 50\%; DPPH and ABTS radicals were scavenged by $50 \%$ and LPO was inhibited by $50 \% .{ }^{\mathrm{B}}$ Expressed as $\mathrm{mM}$ ferrous ions equivalents. ${ }^{\mathrm{C}}$ Expressed as $\mathrm{mM}$ trolox equivalents. * Determined at $10 \mathrm{mg} / \mathrm{mL}$ for the extract and $0.3 \mathrm{mg} / \mathrm{mL}$ for quercetin.

These results are in accordance with previous studies, which reported the efficacy of Centaurea species to prevent the lipid peroxidation [2, 41], scavenge free radicals $[1,34,41]$ and act as reducing agent $[2,14]$. AChE inhibitory activity

Cholinesterase inhibitors are used for the treatment of Alzheimer's disease (AD) and vascular dementia [30]. There are limited reports on the AChE inhibitory activity of Centaurea species. Methanolic extract of C. nerimaniae exhibited modest AChE inhibitory activity of $42.67 \pm 3.05 \%$ at $10 \mathrm{mg} / \mathrm{mL}$ concentration. However, the extract showed less inhibitory activity against $\mathrm{AChE}$ than galantamine $(86.17 \pm 1.44 \%$, at $0.05 \mathrm{mg} / \mathrm{mL}$ concentration). Similarly, the extract from the aerial parts of Centaurea polypodiifolia var. pseudobehen was reported to show $45.50 \%$ inhibition towards both $\mathrm{AChE}$ and buthylcholinesterase (BChE) [2]. The chloroform extract of C. pulchella was reported to have noticeable inhibition value on $\operatorname{AChE~}(95.93 \%)$ and $\mathrm{BChE}(95.69 \%)$ at $2 \mathrm{mg} / \mathrm{mL}$. Otherwise, Boğa et al. [8] reported that the petroleum ether, acetone and methanol extracts of C. balsamita, C. depressa, C. lycopifolia did not show any AChE activity. This difference may be explained by the different extraction procedure and the diversity of phenolic compounds. Roseiro et al. pointed out that a free $\mathrm{OH}$-group at $\mathrm{C} 3$ position of the flavonoids enhanced their AChE inhibitory effect, while the glycosylation or lacking of $\mathrm{OH}$ at $\mathrm{C} 3$ (luteolin and apigenin) do not have a positive effect [38].

Anti-inflammatory activity

The expression of COX-2 is regulated by a broad spectrum of pro-inflammatory mediators, involved in inflammation. The association of COX-2 with inflammation resulted in a search for specific COX2 inhibitors that would provide therapeutic antiinflammatory effects similar to those of NSAIDs but did not cause the unwanted side effects [22].

Many reports suggest that Centaurea species exert antiinflammatory properties in a rat model of inflammatory bowel disease (IBD) [4], carrageenan-induced paw oedema [17, 25], TPA-induced ear oedema formation [26], most probably through the COX-2 inhibition and expression or Nuclear factor- $\kappa \beta$.

The extract of $C$. nerimaniae has been shown to cause $92.16 \pm 3.49 \%$ inhibition of COX-1 and $68.03 \pm 4.90 \%$ inhibition of COX-2 at $10 \mathrm{mg} / \mathrm{mL}$. However, this level of inhibition is significantly lower when compared to indomethacin which was shown to cause $97.1 \pm$ $0.1 \%$ inhibition of COX-1 at $0.005 \mathrm{mg} / \mathrm{mL}$ and $95.92 \pm 2.2 \%$ inhibition of COX-2 at $0.050 \mathrm{mg} / \mathrm{mL}$. Similarly, Centaurea anthiocia has been found to inhibit both COX-1 and COX-2 enzymes [34]. These findings support the reported anti-inflammatory activity of Centaurea species.

Anti-inflammatory activities of Centaurea species have been explained by their content of sesquiterpene lactones (SLs), obtained from many plants of this family [4]. Flavonoids have been reported to display marked in vitro and in vivo anti-inflammatory activities. It was reported that the ability of some flavonoids, such as rutin, quercetin, apigenin and centaureidin, to inhibit cyclooxygenase-2 expression, may contribute to the antiinflammatory properties of Centaurea species [11, 21, 32]. Anti-inflammatory activity of hispidulin, naturally occurring flavone found in $C$. nerimaniae, were investigated in the TPA mouse ear edema model and was found to be active [35].

These findings provide an explanation for the reported anti-inflammatory properties of Centaurea extracts. Antimicrobial activity

Microorganisms used in this study represent pathogenic species mostly associated with nosocomial infections. Antibacterial effect of the extract from $C$. nerimaniae was tested on gram-negative (Escherichia coli, $K$. pneumonia, Pseudomonas aeruginosa, Proteus mirabilis) and gram-positive (Staphlococcus aureus, Streptococcus epidermidis) bacteria, and antifungal effect of the extract was investigated on Candida albicans. The results were displayed in Table IV. The extract exhibited inhibitory activity against all tested strains. C. nerimaniae extract had the greatest potential of antibacterial activity against both gram-positive and gram-negative bacteria with the MICs ranged from 1.25 to $10 \mathrm{mg} / \mathrm{L}$. According to the antibacterial activity results, $S$. aureus was the most sensitive species $(\mathrm{MIC}=1.25 \mathrm{mg} / \mathrm{L})$, followed by $P$. mirabilis $(\mathrm{MIC}=$ $2.5 \mathrm{mg} / \mathrm{L}$ ), $K$. pneumoniae (MIC $=5 \mathrm{mg} / \mathrm{L}), P$. aeruginosa (MIC $=5 \mathrm{mg} / \mathrm{L}$ ) and $S$. epidermidis $(\mathrm{MIC}=10 \mathrm{mg} / \mathrm{mL})$. Moreover, our antifungal activity 
FARMACIA, 2018, Vol. 66, 6

findings showed that C. albicans, the yeast, also was $\quad$ highly sensitive (MIC $=1.25 \mathrm{mg} / \mathrm{L}$ ) to the extract.

Table IV

Antimicrobial activity of methanol extract of $C$. nerimaniae and standards

\begin{tabular}{cccc}
\hline \multirow{2}{*}{ Microorganism } & & \multicolumn{2}{c}{ MIC values $(\mathbf{m g} / \mathbf{m L})$} \\
\cline { 3 - 4 } & & Extract & Standard \\
\hline Gram-positive & S. aureus & 1.25 & $1.2^{\#}$ \\
& S. epidermidis & 10 & $9.8^{\#}$ \\
Gram-negative & E. coli & 5 & $4.9^{\#}$ \\
& K. pneumoniae & 5 & $4.9^{\#}$ \\
& P. aeruginosa & 5 & $2.4^{*}$ \\
Yeast & P. mirabilis & 2.5 & $2.4^{\#}$ \\
& C. albicans & 1.25 & $4.9^{\text {ब }}$ \\
\hline
\end{tabular}

\# cefuroxime; * ceftazidime; "clotrimazole

These results confirmed the findings in the other studies reporting the antibacterial activities of Centaurea species [24, 27, 41, 43, 44]. Further studies will be focused on the in vivo antimicrobial activities and chemical identification of the antimicrobial ingredients with antimicrobial activities close or stronger than tested standard antibiotics or antifungal, clotrimazole.

\section{Conclusions}

The present study reported for the first time the flavonoid profile and biological activities of $C$. nerimaniae. The observed antioxidant, antibacterial, anti-inflammatory and anti-cholinesterase activities may be due to the presence of the five flavonoids (cirsimaritin, hispidulin, apigenin, isokaempferide and apigenin 7-O-glucoside) identified by thin-layer chromatography (TLC). It was concluded that this species has the potential for effective treatment of various illnesses, including inflammation, microbial and $\mathrm{AD}$ diseases.

\section{Acknowledgement}

Scientific Research Projects Coordination Unit of Istanbul University supported this work, Project number 30111.

\section{References}

1. Aktumsek A, Zengin G, Guler GO, Cakmak YS, Duran A, Screening for in vitro antioxidant properties and fatty acid profiles of five Centaurea L. species from Turkey flora. Food Chem Toxicol., 2011; 49: 2914-2920.

2. Aktumsek A, Zengin G, Guler GO, Cakmak YS, Antioxidant potentials and anticholinesterase activities of methanolic and aqueous extracts of three endemic Centaurea L. species. Food Chem Toxicol., 2013; 55: 290-296.

3. Al-easa HS, Rizk AM. Constituents of Centaurea species. Quatar Univ Sci J., 1992; 12: 27-57.

4. Al-Saghir J, Al-Ashi R, Salloum R, Saliba NA, Talhoukand RS, Homaidan FR, Anti-Inflammatory properties of salograviolide A purified from Lebanese plant Centaurea ainetensis. BMC Complem Altern Med., 2009; 9: 36-46.
5. Baytop T, Therapy with medicinal plants in Turkey (Past and Present) $2^{\text {nd }}$ ed. (Nobel Tip Kitapevleri, Istanbul), 1999; 316.

6. Beltagy AM, Chemical composition and cytotoxic activity of Centaurea scoparea Sieb against four human cell lines. J Pharm Sci Res., 2015; 7(3): 103-107.

7. Benzie IFF, Strain JJ, The ferric reducing ability of plasma (FRAP) as a measure of "antioxidant power": The FRAP assay. Anal Biochem., 1996; 239: 70-76.

8. Boga M, Alkan H, Abdulselam Ertaş A, Oral EV, Yılmaz MA, Yeşil Y, Phytochemical profile and some biological activities of three Centaurea species from Turkey. Trop J Pharm Res., 2016; 15(9): 1865-1875.

9. Bona M, An overview to Centaurea (Asteraceae) based on herbarium specimens of ISTE. J Fac Pharm Istanbul, 2013; 43(2): 121-137.

10. Brand-Williams W, Cuvelier ME, Berset C, Use of a free radical method to evaluate antioxidant activity. Food Sci Technol., 1995; 28: 25-30.

11. Calixto JB, Otuki MF, Santos ARS, Anti-inflammatory compounds of plant origin. Part I. Action on arachidonic pathway, nitric oxide and nuclear factor $\kappa \mathrm{B}(\mathrm{NF}-\mathrm{\kappa B})$. Planta Med., 2003; 69: 974-983.

12. Clinical and Laboratory Standards Institute (CLSI). Reference Method for Broth. Dilution Antifungal Susceptbility Testing of Yeasts; Approved Standart M27-A. Wayne PA: CLSI. 2000

13. Clinical and Laboratory Standards Institute (CLSI). Methods for dilution antimicrobial susceptibility tests for bacteria that grow aerobically: Approved Standard M7-A5. Wayne PA: CLSI. 2006

14. Dalar A, Uzun Y, Mukemre M, Turker M, Konczak I, Centaurea karduchorum Boiss. from Eastern Anatolia: Phenolic composition, antioxidant and enzyme inhibitory activities. J Herbal Medicine, 2015; 5(4): 211-216.

15. Duh, PD, Tu, YY, Yen, GC, Antioxidant activity of water extract of Harng Jyur (Chrysanthemum morifolium Ramat). Lebensm Wiss Technol., 1999; 32: 269-277.

16. Ellman GL, Courtney KD, Andres V, Feather-Stone RM, A new and rapid colorimetric determination of acetylcholinesterase activity. Biochem Pharmacol., 1961; 7: 88-95.

17. Erel SB, Demir S, Nalbantsoy A, Ballar P, Khan S, Karabay Yavasoglu NU, Karaalp C, Bioactivity screening of five Centaurea species and in vivo anti-inflammatory activity of $C$. athoa. Pharm Biol., 2014; 52(6): 775-781.

18. Formisano C, Rigano D, Senatore F, Bancheva S, Maggio A, Rosselli S, Bruno M, Flavonoids in subtribe 
Centaureinae (Cass.) Dumort. (Tribe Cardueae, Asteraceae): distribution and ${ }^{13} \mathrm{C}-\mathrm{NMR}$ spectral data. Chem Biodivers., 2012; 9: 2096-2158.

19. Grande M, Piera F, Cuenca A, Torres P \& Bellido IS. Flavonoids from Inula viscosa. Planta Med., 1985; 51: 414-419.

20. Guven K, Celik S, Uysal I, Antimicrobial activity of five endemic Centaurea L. species. Pharm Biol., 2005; 43: 67-71.

21. Havsteen $\mathrm{BH}$, The biochemistry and medical significance of the flavonoids. Pharmacol Ther., 2002; 96: 67-202.

22. Hinz B, Brune K, Cyclooxygenase-2-10 years later. J Pharmacol Exp Ther., 2002; 300: 367-375

23. Karamenderes C, Khan S, Tekwanı B, Jacob M, Khan I, Antiprotozoal and antimicrobial activities of Centaurea species growing in Turkey. Pharm Biol., 2006; 44: 534-539.

24. Karamenderes C, Konyalioglu S, Khan S, Khan IA, Total phenolic contents, free radical scavenging activities and inhibitory effects on the activation of NF-kappa B of eight Centaurea L. species. Phytother Res., 2007; 21: 488-491.

25. Koca U, Suntar IP, Keles H, Yesilada E, Akkol EK, In vivo anti-inflammatory and wound healing activities of Centaurea iberica Trev. ex Spreng. J Ethnopharmacol., 2009; 126: 551-556.

26. Koca U, Toker G, Akkol EK, Assessment of the extracts of Centaurea tchihatcheffii Fischer for anti-inflammatory and analgesic activities in animal models. Trop J Pharm Res., 2009; 8(3): 193-200.

27. Kose YB, Iscan G, Demirci B, Baser KHC, Celik S, Antimicrobial activity of the essential oil of Centaurea aladagensis. Fitoterapia, 2007; 78: 253-254.

28. Kültür Ş, Centaurea nerimaniae sp. nov. Asteraceae from sought Anatolia, Turkey. Nord J Bot., 2010; 28: 613-616.

29. Mabry TJ, Markham KR, Thomas MB, The systematic identification of flavonoids. Springer- Verlag Inc New York (NY), 1970.

30. May BH, Lit M, Xue CC, Yang AW, Zhang AL, Owens MD, Head R, Cobiac L, Li CG, Hugel H, Story DF, Herbal medicine for dementia: a systematic review. Phytother Res., 2009; 23: 447-459.

31. Nikolova M, Bancheva S, Surface flavonoids of Centaurea stenolepis and the local endemics Centaurea davidovii and C. parilica (Asteraceae, sect. Lepteranthus) from Bulgaria. Phytologia Balcanica, 2013; 19(3): 357-360.

32. Orallo F, Lamela M, Camina M, Uriatre E, Calleja M, Preliminary study of the potential vasodilator effects on rat aorta of centaurein and centaureidin, two flavonoids from Centaurea corcubionensis. Planta Med., 1998; 64: 116-119.

33. Ozkan G, Kamiloglu S, Ozdal T, Boyacioglu D, Capanoglu E, Potential use of Turkish medicinal plants in the treatment of various diseases. Molecules, 2016; 21: 257-289

34. Ozsoy N, Kultur S, Yilmaz-Ozden T, Ozbek-Celik B, Can A, Melikoglu G, Antioxidant, anti-inflammatory, acetylcholinesterase inhibitory and antimicrobial activities of Turkish endemic Centaurea Antiochia var. praealta. J Food Biochem., 2015; 39(6): 771-776.

35. Patel K, Patel DK, Medicinal importance, pharmacological activities, and analytical aspects of hispidulin: A concise report. J Tradit Complemen Med., 2016; 7(3): 360-366.

36. Rauter P, Branco I, Tostao Z, Pais MS, Gonzalez GA, Bermejo JB, Flavonoids from Artemisia campestris subsp. maritima. Phytochemistry, 1989; 28(8): 21732175.

37. Re R, Pellegrini N, Proteggente A, Pannala A, Yang $\mathrm{M}$, Rice-Evans C, Antioxidant activity applying an improved ABTS radical cation decolorization assay. Free Radical Bio Med., 1999; 26: 1231-1237.

38. Roseiro LB, Rauter AP, Serralheiro MLM, Polyphenols as acetylcholinesterase inhibitors: Structural specificity and impact on human disease. Nutrition and Aging, 2012; 1: 99-111.

39. Sakanaka S, Tachibana Y, Okada Y. Preparation and antioxidant properties of extracts of Japanese persimmon leaf tea (kakinoha-cha). Food Chem., 2005; 89: 569-575.

40. Saleh NAM, El-Negoumy SI, Abou-ZXard M, Flavonoids of Artemisia judaica, A. monosperma and A. herbaalba. Phytochemistry, 1987; 26(11): 3059-3054.

41. Sen A, Bitiș L, Birteksöz-Tan S, Bulut $\mathrm{G}$, In vitro evaluation of antioxidant and antimicrobial activities of some Centaurea L. species. Marmara Pharmaceutical Journal, 2013; 17: 42-45.

42. Slinkard K, Singleton VL, Total phenol analyses: Automation and comparison with manual methods. Am J Enol Viticult., 1977; 28: 49-55.

43. Tekeli Y, Zengin G, Aktümsek A, Sezgin M, Torlak E, Antibacterial activities of extracts from twelve Centaurea species from Turkey. Arch Biol Sci., 2011; 63: 685-690.

44. Ugur A, Sarac N, Ceylan O, Duru ME, Chemical composition of endemic Centaurea austro-anatolica and studies of its antimicrobial activity against multiresistant bacteria. Acta Pharm., 2009; 99: 463-472.

45. Uysal S, Ceylan R, Zengin G, Aktumsek A, Zengin N, Guler GO, Phytochemical characterization of an endemic plant used as foodstuff in Turkey: Centaurea urvillei subsp. stepposa and its antioxidant properties. Int Res J Pharmacy (IRJP), 2014; 5: 646-652.

46. Zengin G, Cakmak YS, Guler GO, Aktumsek A, In vitro antioxidant capacities and fatty acid compositions of three Centaurea species collected from Central Anatolian region of Turkey. Food Chem Toxicol., 2010; 48: 2638-2641.

47. Zengin G, Aktumsek A, Guler GO, Cakmak YS, Antioxidant properties of methanolic extract and fatty acid composition of Centaurea urvillei DC. subsp. hayekiana Wagenitz. Rec Nat Prod., 2011; 5: 123-132.

48. Zengin G, Aktumsek A, Guler GO, Cakmak YS, Kan $\mathrm{Y}$, Comparison of essential oil and antioxidant capacity of Centaurea drabifolia Sm. subsp. detonsa (Bormm) Wagenitz, endemic to Turkey. Nat Prod Res., 2012; 26: 1-10. 